\title{
Phototherapy Induced Hypocalcemia in Neonatal Hyperbilirubinemia
}

\author{
Dr. Pankaj Kumar Singh ${ }^{1}$,Dr. Partha Kumar Chaudhuri ${ }^{2}$, \\ Dr. Anil Kr Chaudhary ${ }^{3}$ \\ Junior Resident ${ }^{1}$, Associate Professor ${ }^{2}$, Professor ${ }^{3}$. \\ Department Of Pediatrics And Neonatology, Rajendra Institute Of Medical Sciences, Ranchi, Jharkhand, India
}

\begin{abstract}
:
Background:- Jaundice is an important problem in the $1^{\text {st }}$ week of life affecting approximately $60 \%$ of term and $80 \%$ of preterm infants. It is commonly managed by phototherapy. Phototherapy may result in the development of hypocalcemia \& create serious complications including seizures \& other condition.

Objective:- To study the effect of phototherapy on serum calcium is neonatal hyperbilirubiniea.

Design: - Prospective hospital based comparative study

Material and Methods :- This was a prospective hospital based comparative study at Neonatal Intensive Care Unit (NICU) of Rajendra Institute Of Medical Sciences, Ranchi from June 2015 to may 2016 after taking ethical committee approval. The study group includes 60 neonates (40 term and20 preterm). All had hyperbilirubinemia. All the neonates included in the study group required phototherapy. The neonates in the control group were managed without phototherapy. Serum bilirubin \& serum calcium were determined before \& after 48 hour of phototherapy.

Results:- After 48 hour phototherapy in study group, a significant tall in calcium level in $30 \%$ of term \& $70 \%$ of preterm neonates was observed ( $p$ value <0.001). Whereas, no difference was observed in control group. Phototherapy induced hypocalcemia is a significant problem especially in preterm neonates.
\end{abstract}

Keywords: Hyperbilirubinemia, Phototherapy, Hypocalcemia, Neonates

\section{Introduction}

The Jaundice is an important problem in the first week of life affecting approximately $60 \%$ of term and $80 \%$ of preterm infants ${ }^{(1)}$. Jaundice is attributable to physiological immaturity of neonates to handle increased bilirubin production. Basic pathophysiology of jaundice is same in term and preterm neonates, but premature babies are at a higher risk of developing hyperbilirubinemia. Phototherapy is the most widely used form of therapy for newborn infants with hyperbilirubenia in order to decrease the body burden of neurotoxic bilirubin $^{(2,3)}$. The commonly known side effects of phototherapy are loose stools, hyperthermia, dehydration fluid loss, skin burn, photoretinitis, low platelet count, increased red cell osmotic fragility, bronze baby syndrome, riboflavin deficiency and DNA damage and hypocalcemia. Neonatal hypocalcemia is defined as total serum calcium concentration of $<7 \mathrm{mg} / \mathrm{dl}$ or ionized calcium concentration of $<4 \mathrm{mg} / \mathrm{dl}(<1 \mathrm{~mol} / \mathrm{L})$. Calcium is crucial for many biochemical processes, including blood coagulation, neuromuscular excitability, cell membrane integrity and function, and cellular enzymatic and secretory activity.

Hakinsons ${ }^{(6)}$ and Hunter ${ }^{(5)}$ hypothesized that phototherapy inhibits pineal secretion of melatonin which blocks the effect of cortisol on bone calcium . so cortisol increases bone uptake of calcium and induces hypocalcaemia. $\mathrm{Kim}^{(7)}$ suggested decreased secretion of parathormone as the cause of hypocalcemia. In Hooman's study the urinary calcium excretion was significantly higher in phototherapy group. Romagnoli et al (1979) for the first time suggested the association of hypocalcemia with phototherapy in preterm newborns. Similarly Hakanson \& Bergstrom (1981) documented this observation in newborn rats. There are few studies on hypocalcaemic effect of phototherapy (Tan 1991; Sethi et al, 1993; Hakanson \& Bergstrom, 1981).

\section{Material and Methods}

This was a prospective hospital based comparative study at Neonatal Intensive Care Unit (NICU) of Rajendra Institute Of Medical Sciences, Ranchi from June 2015 to may 2016 after taking ethical committee approval. The study group includes 60 neonates (40 terms and 20 preterm). All had hyperbilirubinemia. All the neonates included in the study group required phototherapy. The neonates in the control group having hyperbilirubinemia in physiological range and were managed without phototherapy. . Serum bilirubin \& serum calcium were determined before $\&$ after 48 hour of phototherapy. Phototherapy was provided with four blue and two white lights placed at $30 \mathrm{~cm}$ from the neonates and delivering at least $20 \mu \mathrm{W} / \mathrm{cm}^{2} / \mathrm{nm}$. 


\begin{tabular}{|c|l|l|l|l|}
\hline \multirow{2}{*}{} & \multicolumn{2}{|c|}{ Study } & \multicolumn{2}{c|}{ Central } \\
\cline { 2 - 5 } & group $(\mathrm{n}=60)$ & group $(\mathrm{n}=20)$ & Preterm(n=10) \\
\cline { 2 - 5 } & Term $(\mathrm{n}=40)$ & Preterm(n=20) & Term $(\mathrm{n}=10)$ & $14.25 \pm 2.2$ \\
\hline Pre-study & $15.45 \pm 3.0$ & $18.7 \pm 1.65$ & $12.25 \pm 2.2$ & $14.34 \pm 1.6$ \\
\hline Post-study & $10.15 \pm 0.97$ & $11.85 \pm 0.9$ & $12.35 \pm 1.6$ & $\mathrm{P}=0.96$ \\
\hline P-value & $\mathrm{P}<0.05$ & $\mathrm{P}<0.05$ & $\mathrm{P}=0.9$ & \multicolumn{2}{|c}{} \\
\hline
\end{tabular}

\section{Inclusion criteria :-}

1. Neonates receiving phototherapy for unconjugated hyperbilirubinemia.

\section{Exclusion criteria:-}

1. Neonates with conjugated hyperbilirubinemia.

2. Neonates who had developed a complication during the course of phototherapy.

3. Neonates with co morbidities like :-

a. Birth asphyxia

b. Respiratory distress

c. Septicemia

d. Neonates with electrolyte imbalance

e. Renal failure.

4. Neonates requiring exchange transfusion

5. If jaundice appear within 24 hour of life.

6. Infants of diabetic mother etc.

A detailed antenatal, perinatal history and examination of neonates was done in all case of study and control group. Serum calcium was measured pre and post phototherapy of 48hrs, complete blood count, C reactive protein, S. bilirubin, blood groups of baby and mother was done as routine investigation in all cases. Total \& direct bilirubin is measured by Diazo method, calcium by Arsenazo method. Blood group of newborn was analyzed by antisera method. Neonates were assessed for features of hypocalcemia i.e. seizures, apnea, jitteriness, increased extensor tone, clonus, hyperreflexia and stridors. Electrolytes were checked at 0 hour (first sample) and at 48 hours of phototherapy or at discontinuation of phototherapy (second sample) whichever is earlier. The first sample was considered as control.

\section{Result}

1. The Incidence of neonatal jaundice was $35 \%$ in this study.

2. Preterm neonates were $33 \%$ and $67 \%$ cases were term neonates in the present study.

3. The mean weight of cases in the preterm and term groups was $1.5 \mathrm{~kg} \pm 0.5$ and $2.7 \mathrm{~kg} \pm 0.2$ respectively.

4. Majority of preterm babies (50\%) developed jaundiced in day 2, while approximately $65 \%$ term babies developed it on day 3.

5. All the neonates responded to phototherapy and none of them required exchange transfusion

6. The mean serum bilirubin in jaundiced preterm babies showed a significant decline from $18.70 \mathrm{mg} / \mathrm{dl}$ \pm 1.65 to $11.85 \mathrm{mg} / \mathrm{dl} \pm 0.90$ after phototherapy $(\mathrm{p}<0.005)$.

7. There was also a significant decline in mean serum bilirubin levels in terms babies from $15.45 \mathrm{mg} / \mathrm{dl} \pm 3$ to $10.15 \mathrm{mg} / \mathrm{dl} \pm 0.97(\mathrm{p}<0.05)$.

8. $70 \%$ of preterm and $30 \%$ of term neonates developed hypocalcemia.

9. The mean serum calcium levels in the preterm showed statistically significant fall from $8.41 \mathrm{mg} / \mathrm{dl} \pm 0.466$ to $7.1 \mathrm{mg} / \mathrm{dl} \pm 0.793(\mathrm{p}<0.05)$. A similar decline in the mean serum calcium level was seen in term babies (from $9.52 \mathrm{mg} / \mathrm{dl} \pm 0.53$ to $8.42 \mathrm{mg} / \mathrm{dl} \pm 1.19)(\mathrm{p}<0.05)$.

10. Symptomatic hypocalcemia was seen in $35.7 \%$ of preterm and $25 \%$ of term babies. Jitteriness was the most common complications observed in both preterm $(60 \%)$ and term $(75 \%)$ neonates. Irritability was seen in $40 \%$ of preterm and $25 \%$ of term babies. Apnea and convulsion were not seen in any of the study groups.

Table-1: Calcium levels, pre-phototherapy and post-phototherapy in cases and controls.

Table-2: Symptoms in study subjects.

\begin{tabular}{|l|l|l|}
\hline Symptoms & preterm & term \\
\hline Jitteriness & $3(60 \%)$ & $3(75 \%)$ \\
\hline Irritability & $2(40 \%)$ & $1(25 \%)$ \\
\hline Apnea/convulsion & 0 & 0 \\
\hline
\end{tabular}


Table-3:-Distribution of cases post phototherapy.

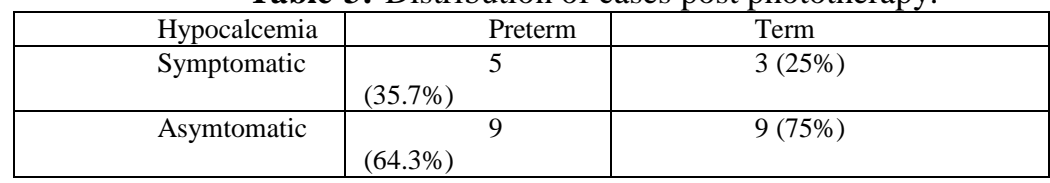

\section{Discussion}

The incidence of neonatal hyperbilirubinemia among admitted newborns in NICU was $35 \%$ in the present study. Anand VR has reported the incidence of neonatal jaundice in total nursery admission as $54.6 \%$. In the present study, jaundice in preterm babies was observe in approximately $50 \%$ on day two,30\% on day three and $15 \%$ on day four, while in term newborns, it was $25 \%$ on day two,65\% on day three and $10 \%$ on day four. The mean serum calcium concentration in preterm (pre study) was similar in both case and control groups. The mean serum calcium level in case group was decreased significantly after giving phototherapy from 8.41 $\mathrm{mg} / \mathrm{dl} \pm 0.47$ to $7.1 \mathrm{mg} / \mathrm{dl} \pm 0.79$ ( $\mathrm{p}<0.05$ ) while in control group (after 48 hours), it was from $9.66 \mathrm{mg} / \mathrm{dl} \pm 0.45$ to $9.6 \mathrm{mg} / \mathrm{dl} \pm 0.64(\mathrm{p}=0.82)$. Difference has been analysed statistically by applying t-test and come out to be statistically significant $(\mathrm{p}<0.05)$.

Table 4: Comparison of mean serum calcium levels before and after phototherapy in preterm neonates with other study

\begin{tabular}{|c|c|c|c|}
\hline \multirow[t]{2}{*}{ Study } & \multicolumn{2}{|c|}{ Mean SD serum calcium level } & \multirow[t]{2}{*}{$\mathrm{P}$ value } \\
\hline & $\begin{array}{c}\text { Before } \\
\text { phototherapy }(\mathrm{mg} / \mathrm{dl})\end{array}$ & $\begin{array}{c}\text { After } \\
\text { phototherapy }(\mathrm{mg} / \mathrm{dl})\end{array}$ & \\
\hline $\begin{array}{ll}\text { et } \mathrm{al}^{(9)} & \text { Karamifar } \\
\end{array}$ & $8.73 \pm 1.38$ & $8.40 \pm 1.71$ & 0.039 \\
\hline Our study & $8.41 \pm 0.47$ & $7.1 \pm 0.79$ & $<0.05$ \\
\hline
\end{tabular}

The mean serum calcium level in term (pre study) was similar in both cases and control groups. The mean serum calcium level in case group decreased after giving phototherapy from $9.52 \mathrm{mg} / \mathrm{dl} \pm 0.53$ to $8.42 \mathrm{mg} / \mathrm{dl}$ \pm 1.19 ( $\mathrm{p}<0.05$ ) and in control group (after 48 hours) it was from $9.64 \mathrm{mg} / \mathrm{dl} \pm 0.45$ to $9.7 \mathrm{mg} / \mathrm{dl} \pm 0.48(\mathrm{p}=0.88$ ). Difference has been analysed statistically by applying t test and come out to be statistically significant $(\mathrm{p}<0.05)$.

Table 5: Comparison of mean serum calcium levels before and after phototherapy in term neonates with other studies

\begin{tabular}{|c|c|c|c|}
\hline \multirow{2}{*}{ Study } & \multicolumn{2}{|c|}{ Mean \pm SD serum calcium level } & \multirow{2}{*}{ p value } \\
\cline { 2 - 3 } & $\begin{array}{c}\text { Before } \\
\text { phototherapy(mg/dl) }\end{array}$ & $\begin{array}{c}\text { After } \\
\text { phototherapy(mg/dl) }\end{array}$ & \\
\hline Eghbalian et al $^{(10)}$ & $9.85 \pm 1.23$ & $9.09 \pm 0.93$ & $<0.001$ \\
\hline Karamifar et al $^{(9)}$ & $9.53 \pm 0.92$ & $9.30 \pm 1.11$ & 0.043 \\
\hline Taheri et al $^{(11)}$ & $9.8 \pm 0.80$ & $9.5 \pm 0.90$ & $<0.05$ \\
\hline Our study & $9.52 \pm 0.53$ & $8.42 \pm 1.19$ & $<0.05$ \\
\hline
\end{tabular}

The incidence of symptomatic and asymptomatic hypocalcaemia induced by phototherapy is shown in table-10 in the present study. The hypocalcaemia was predominantly symptomatic in preterm newborns (35.7\%) as compared to term newborns $(25 \%)$. Karamifar H et al $(2002){ }^{(9)}$ observed hypocalcaemia in $14.4 \%$ of total icteric newborns. There were significant difference between the prevalence of hypocalcaemia in preterm $(22.6 \%)$ and term neonates $(8.7 \%)(\mathrm{p}=0.018)$. Jitteriness was the most common symptom observed in symptomatic hypocalcaemia preterm $(60 \%)$ and term $(75 \%)$ babies. Out of 20 babies, $40 \%$ of preterm babies and $25 \%$ of term babies developed irritability. None of the preterm and term babies developed apnoea and convulsions.

\section{Conclusion}

Neonate requiring phototherapies for hyperbilirubinemia are at higher risk for development of hypocalcemia. This risk is even more in case of preterm babies. Therefore, timely monitoring of serum calcium levels and calcium supplementation is suggested.

\section{References}

[1]. Rennie, J.,et al., Neonatal jaundice: summary of NICE guidance. British Medical Journal 2010;340:240-2499.

[2]. Fanaroff A, Wlash M. Neonatal-Perinatal Medicine,Diseases of the Fetus and Infant, 9 ${ }^{\text {th }}$ edn, Elsevier Mosby, $2010 ;$ Pp:1443-1481.

[3]. Porter ML, Dennis BL, Hyperbilirubinemia in the term newborn. Am Fam Physician. 2002;65;599-606.

[4]. Xiong T, Qu Y, Cambrier S, et al. The side effects of phototherapy for neonatal jaundice: What do we know? What should we do? Eur J Pediatr; 2011;170(10): 1247-55. 
[5]. Hunter KM, Hypocalcemia. In: Cloherty JP, Eichenwald CE, Strak AR(eds). Manual of Neonatal Care $5^{\text {th }}$ ed. Philadelphia: Lippincott wiliams \& Wilkins., 2004;579-88.

[6]. Hakanson D, Penny R, Bergstrom WH. Calcemic responses to photic and pharmacologic manipulation of serum melatonin. Pediatr Res., 1987; 22(4):414-6.

[7]. Kim SH, Park JH. Effect of phototherapy on bone metabolism in newborn rats. J Korean Soc Neonatal, 2001;8(2):206-10.

[8]. Hooman N, Honarpisheh A. The effect of phototherapy on urinary calcium excretion in newborns. Pediatr Nephrol, 2005;20(9): 1363-4.

[9]. Karamifar H, Pishva N, Amirhakimi GH. Prevalence of Phototherapy Induced hypocalcemia. IJMS2002;27(4):166-168 .

[10]. Eghnalian F. Monsef A. Phototherapy induced hypocalcemia in icteric newborns IJMAS 2002;27(4):169-71.

[11]. Taheri PA, Sajjadian N, Eivazzadeh B. Prevalance of phototherapy induced hypocalcemia in term neonate. Iran J Pediatr 2013;23(6):710-11. 